\title{
Hunting in Afghanistan: variation in motivations across species
}

\author{
Mujtaba Bashari, Erin Sills, M. Nils Peterson and Frederick Cubbage
}

\begin{abstract}
Illegal hunting is a widespread problem, with motivations varying across regions. We investigated the patterns and reasons for hunting in Afghanistan, where it is generally illegal but pervasive in the wake of decades of civil war. To assess motivations for hunting, firstly we conducted a systematic review of the literature, extracting information from 32 studies that discuss the relative importance of various reasons for hunting in Afghanistan; we analysed findings from these studies using the meta-analytic method of vote-counting. Secondly, using face-to-face interviews or a web-based questionnaire, we surveyed key informants in Afghanistan about the motivations identified in the literature. We obtained responses from 57 people familiar with hunting, including government officials, vendors in wildlife markets, and hunters. Findings from the meta-analysis and the survey were broadly consistent, both identifying the market for fur and other by-products as one of the most important motivations for hunting. However, much of the published literature focuses on hunting of carnivores, and emphasizes retaliation as a motivation for hunting. Key informants were more likely to cite subsistence consumption and to suggest that providing education and livelihood alternatives would reduce hunting. Our results highlight the importance of a multi-pronged policy response that recognizes variation in motivations for hunting different species.
\end{abstract}

Keywords Afghanistan, human-wildlife conflict, hunting, meta-analysis, poaching, retaliation killing, subsistence

\section{Introduction} he patterns of, and motivations for, illegal hunting vary
across regions and countries. A review of research on motivations for illegal hunting (von Essen et al., 2014) found that economic factors, including commercial gain and household consumption, occupy a large place in the global literature (e.g. Mancini et al., 2011), but recreational satisfaction, securing trophies, protecting people and property, retaliatory killing, poaching as a traditional right,

Mujtaba Bashari Department of Forestry and Natural Resources, Faculty of Agriculture, Kabul University, Kabul City, Afghanistan

Erin Sills (Corresponding author), M. Nils Peterson and Frederick Cubbage Department of Forestry and Environmental Resources, North Carolina State University, Box 8008, Raleigh, NC 27695, USA

E-mail sills@ncsu.edu

Received 15 April 2016. Revision requested 24 May 2016.

Accepted 19 September 2016. First published online 27 February 2017. and ignorance of, or disagreement with, particular game and wildlife regulations are also important (Manning, 1993; Eliason, 2004; Osborne \& Winstanley, 2006; Boglioli, 2009; Raichev \& Georgiev, 2012). Motivations are highly context dependent; for example, the main reason people poach in Namibia is to generate income and food (Kahler \& Gore, 2012), whereas in South Africa organized crime plays a key role in rhinoceros poaching (Ayling, 2013). These have different implications for the design of interventions to combat illegal hunting. In Afghanistan it was previously reported that wildlife is hunted for local consumption, sport, and export to international markets (UNEP, 2003). However, there has been little scientific research on the status of wildlife in Afghanistan, and the threats it faces, for several decades, largely because of the devastating effects of war on the country. As a result, the published literature is neither comprehensive nor current. Thus, we systematically reviewed findings from both the grey and published literature and interviewed key informants to assess the factors that lead to hunting of various species in Afghanistan.

Afghanistan's natural resources are key to the country's economic, social and political stability, with $70-80 \%$ of the population directly or indirectly reliant on agriculture, animal husbandry, and natural resources (UNEP, 2013). Environmental degradation and threats to wildlife are rooted in decades of war. Following Soviet occupation during 1979-1991 Afghanistan experienced almost 20 years of civil war, which degraded both natural and human resources and left Afghanistan vulnerable to natural disasters and food shortages (UNEP, 2003). Food and fuel shortages during the war reportedly led to increased dependence on natural resources, severely harming wildlife and habitats (Formoli, 1995). As of $200678 \%$ of people lived in the countryside, and almost $68 \%$ of the rural population was categorized as economically poor (UNDP, 2006). Most of the rural poor survive on natural resources, either directly or indirectly. As a result, wildlife and habitats have suffered exploitation. People harvest wood for fuel and construction from forests and woodlands. They also kill wildlife for meat and pelts for family use, in retaliation for killing of livestock, and for sale in international markets. Iconic wildlife species, such as the snow leopard Uncia uncia and the Marco Polo sheep Ovis ammon polii, have been exploited, along with many less charismatic species (UNEP, 2003). Although there was practically no field research on wildlife during the decades of war (and in many cases previous data were lost), concern about the status of the country's wildlife has led the government to make all hunting illegal. 
In 2005 presidential decree no. 53 banned hunting in Afghanistan, making all hunting of wild species illegal for 5 years. In 2010 the National Environmental Protection Agency proposed extending decree no. 53 for 5 more years, with the same power and extent. In response, President Karzi issued Hukum no. 1700, stating that 'hunting of rare wild animals and birds that are exposed to extinction, especially Marco Polo sheep, eagle and falcon, and their export to other countries is strictly prohibited.' Consequently the National Environmental Protection Agency and the Ministry of Agriculture, Irrigation and Livestock established the Afghanistan Wildlife Executive Committee to recommend lists of protected and harvestable species. The Committee designated some species as protected and argued that all species are protected until their status has been assessed. One plausible interpretation of this situation is that all hunting in Afghanistan is illegal, reflecting the conservation perspective of western organizations and governments active in Afghanistan. This means that all of the reasons people traditionally hunted in Afghanistan may now be motivations for illegal hunting (cf. Peterson et al., 2016).

Research synthesis provides the basis for evidence-based policy or, more broadly, evidence-informed decision making (Atmadja \& Sills, 2015). We synthesized the research on hunting in Afghanistan by searching systematically for all studies of hunting in the country, following a transparent and replicable search protocol. To summarize these studies we used the vote-counting approach to meta-analysis, identifying both how many studies considered a particular factor and how many studies found that factor to be a motivation or the most important motivation for hunting. As the literature is relatively sparse, we supplemented our meta-analysis with a survey of people familiar with hunting and the wildlife trade in Afghanistan. The survey generally confirmed our research synthesis but provided more detail on how the motivations and drivers of hunting vary across species. We present results from both the systematic review and the survey, to provide a basis for evidence-based wildlife policy in Afghanistan.

\section{Methods}

Given the challenges involved in conducting research in Afghanistan, we assessed motivations for hunting through (1) a systematic search of both the scientific and the grey literature for studies relevant to the subject, and (2) a survey of key informants, interviewed in-person or through a webbased form. We defined hunting as shooting, trapping, fishing, and any other method of killing or taking wild animals. Based on our initial screening of the literature we identified the following potential motivations and drivers for hunting: subsistence consumption, medicinal needs, retaliation, trade in fur and other by-products (including horn, ivory, bone, claws and feathers), pet and live trade, demand in international markets, and recreation (including trophy hunting). In a final review of the literature we found several other factors commonly mentioned, including gun availability, commercial gain, decoration and taxidermy. We also asked key informants about demand for wildlife by foreigners living and working in Afghanistan (e.g. military forces) and for trophy hunting by foreigners, which have both been reported in the media.

\section{Meta-analysis methodology}

We systematically searched, screened and extracted information on the factors associated with hunting from the literature, in a four-step process (identification, screening, eligibility, and inclusion criteria) based on the PRISMA flow diagram (Fig. 1; Moher et al., 2009). We used the following keywords in our final search of the literature: wildlife conservation; illegal wildlife trade; hunting drivers; wildlife international demand; wildlife national demand; household wealth and wildlife consumption; poverty and wildlife consumption; wildlife medical usages; wildlife fur and byproduct; gun availability; technology and wildlife hunting; wildlife retaliation; wildlife live trade; trophy hunting; and Afghanistan wildlife endangered species.

In the first step 321 articles in total were identified through searches of (1) Google Scholar $(n=185)$, (2) the academic databases Science Direct, Springer Link, Scopus and the North Carolina State University libraries website $(\mathrm{n}=72)$, and (3) resource lists provided by key organizations and professional networks in Afghanistan $(\mathrm{n}=64)$. After removing duplicate papers and articles, and screening titles, abstracts and full text, we found 72 papers that discussed motivations and drivers of hunting in Afghanistan. Of those, 32 provided quantitative information and were therefore used in the meta-analysis; the remainder $(n=40)$ were used in a qualitative synthesis (Fig. 1). We used both published and unpublished studies, including annual reports, technical reports and summaries of survey results. Of the 32 quantitative studies, 14 had been published and 18 were unpublished. Eight of these studies drew on results from prior research, and 24 reported new research findings.

Search details To limit the effect of publication bias we collected PhD dissertations, MSc theses, grey literature, and both peer-reviewed and non peer-reviewed published articles (Benítez-López et al., 2010). We complemented this search by scanning the bibliographies of articles found using the keyword searches (cf. Benítez-López et al., 2010) and by contacting the authors and subject-matter experts (CEBC, 2009). We also searched Science Direct, Springer Link, Web of Science, Scopus (CEBC, 2009), and North Carolina State University libraries, as well as online catalogues and resource lists provided by relevant organizations and professional networks (CEBC, 2009), particularly Afghanistan's governmental organizations 


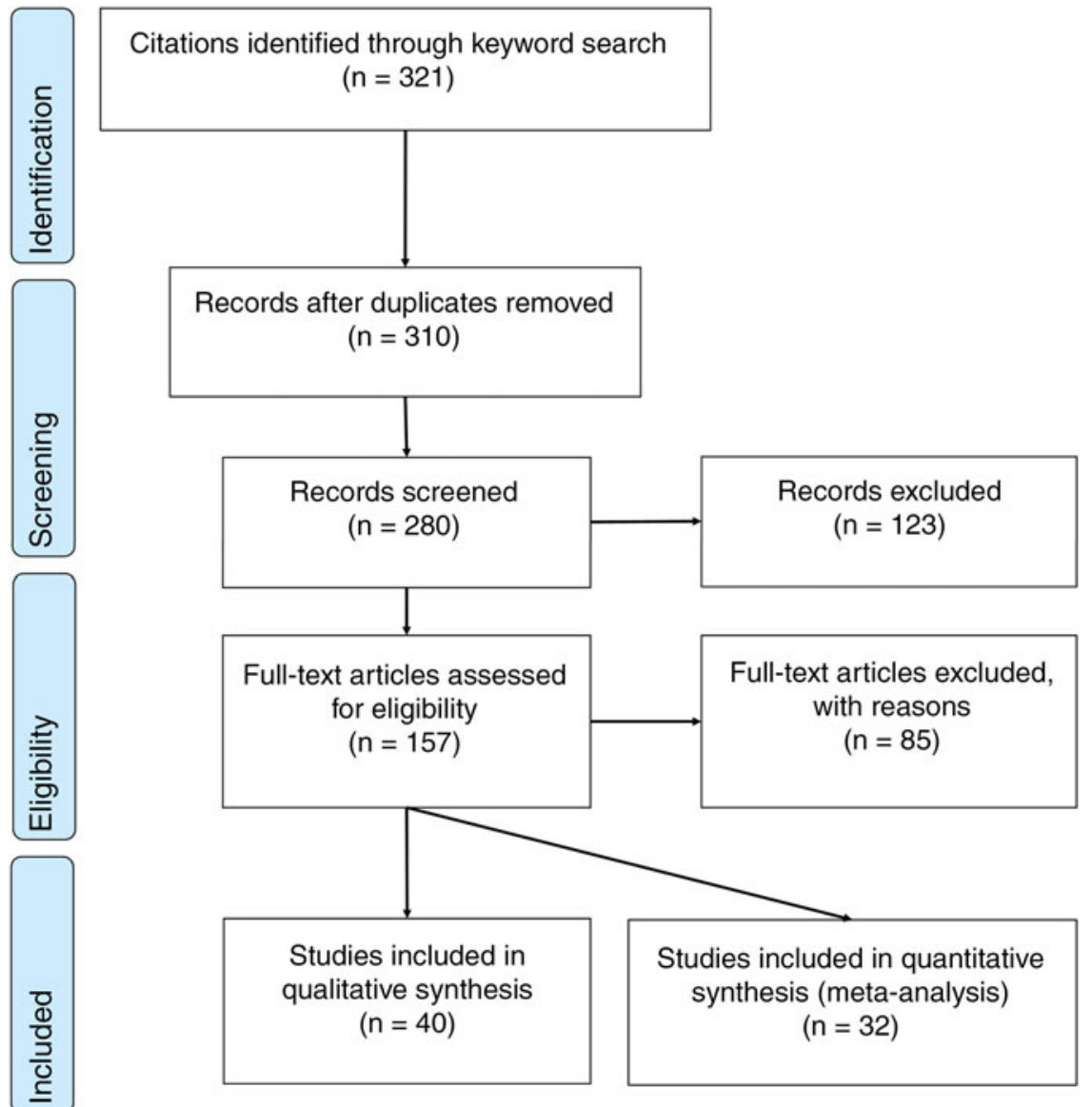

FIG. 1 Results of systematic literature search to assess motivations for hunting in Afghanistan.

responsible for wildlife management, including the Ministry of Agriculture, Irrigation and Livestock, and the National Environmental Protection Agency. In addition, we contacted relevant NGOs, such as the Wildlife Conservation Society, identified based on MB's contacts in Afghanistan.

Screening Once we completed the search we screened the materials (CEBC, 2009) in three phases: (1) We retained sources whose titles and abstracts included relevant instances of our pre-identified keywords (e.g. wildlife conservation; illegal wildlife trade; poaching motivation; wildlife international demand; and wildlife national demand). (2) We reviewed the abstracts to verify that the materials related to hunting in Afghanistan. (3) We reviewed the full text of 157 papers, retaining the 72 that addressed motivations for hunting in Afghanistan.

Data coding and analysis For the quantitative analysis we counted the number of studies that reached conclusions about 12 factors associated with hunting in Afghanistan, which included motivations (hunting for subsistence consumption, medicinal use, recreation, decoration, pet and live trade, trade in fur and other by-products, taxidermy, trophy hunting and retaliation) and more general contextual factors (international demand, commercial value, and availability of guns). The last three factors facilitate and encourage hunting, including opportunistic or unplanned hunting. As different species are hunted for different purposes, we coded motivations for hunting species in three groups: carnivores, ungulates and birds. In the 32 studies that we considered, we identified 252 reports on whether particular factors influence hunting, including 210 reports of factors that influence hunting of particular species groups (Table 1). The vote-counting method provides a suitable starting point for synthesizing results from various studies and papers (Pattanayak et al., 2003). To implement this method we counted the numbers of studies that (1) considered, (2) found to be important, and (3) judged to be the most important, each of the 12 factors listed above, both overall and for each of the three species groups. Each study that found a factor to be important (category 2) was considered to be a vote for that factor (Pattanayak et al., 2003). We identified factors considered to be the most important (category 3) based on the authors' discussion of their findings.

\section{Survey methodology}

Survey procedure Because there was no sampling frame available and because we believed that people approached through a random intercept survey would be unwilling to 
TABLE 1 Results of vote-counting meta-analysis of the literature on motivations for hunting in Afghanistan, with the numbers of cases (overall and in studies focusing on particular groups of species) that found a particular motivation to be irrelevant, relevant, and most important, as well as the total number of cases in which each motivation was considered.

\begin{tabular}{|c|c|c|c|c|c|c|c|c|c|c|c|c|c|c|c|c|}
\hline \multirow[b]{2}{*}{$\begin{array}{l}\text { Motivations for } \\
\text { hunting }\end{array}$} & \multicolumn{4}{|l|}{ Overall $^{1}$} & \multicolumn{4}{|c|}{ Carnivores $^{2}$} & \multicolumn{4}{|c|}{ Ungulates $^{3}$} & \multicolumn{4}{|l|}{ Birds $^{4}$} \\
\hline & $\begin{array}{l}\text { Not } \\
\text { relevant }\end{array}$ & Relevant & Important & Total & $\begin{array}{l}\text { Not } \\
\text { relevant }\end{array}$ & Relevant & Important & Total & $\begin{array}{l}\text { Not } \\
\text { relevant }\end{array}$ & Relevant & Important & Total & $\begin{array}{l}\text { Not } \\
\text { relevant }\end{array}$ & Relevant & Important & Total \\
\hline $\begin{array}{l}\text { Subsistence } \\
\text { consumption }\end{array}$ & 3 & 2 & 20 & 25 & 0 & 0 & 0 & 0 & 1 & 1 & 11 & 13 & 1 & 1 & 4 & 6 \\
\hline Medicine & 0 & 1 & 6 & 7 & 0 & 0 & 2 & 2 & 0 & 0 & 0 & 0 & 0 & 0 & 3 & 3 \\
\hline $\begin{array}{l}\text { Recreational } \\
\text { hunting }\end{array}$ & 1 & 3 & 1 & 5 & 0 & 0 & 0 & 0 & 0 & 0 & 1 & 1 & 0 & 0 & 0 & 0 \\
\hline Decoration & 0 & 1 & 1 & 2 & 0 & 0 & 0 & 0 & 0 & 0 & 1 & 1 & 0 & 0 & 0 & 0 \\
\hline Live trade & 0 & 5 & 20 & 25 & 0 & 1 & 6 & 7 & 0 & 1 & 0 & 1 & 0 & 2 & 13 & 15 \\
\hline $\begin{array}{l}\text { Fur \& other } \\
\text { by-products }\end{array}$ & 4 & 24 & 46 & 74 & 2 & 20 & 37 & 59 & 0 & 1 & 4 & 5 & 0 & 0 & 1 & 1 \\
\hline Taxidermy & 0 & 1 & 0 & 1 & 0 & 0 & 0 & 0 & 0 & 0 & 0 & 0 & 0 & 0 & 0 & 0 \\
\hline $\begin{array}{l}\text { International } \\
\text { demand }\end{array}$ & 0 & 1 & 4 & 5 & 0 & 0 & 0 & 0 & 0 & 0 & 0 & 0 & 0 & 1 & 2 & 3 \\
\hline $\begin{array}{l}\text { Commercial } \\
\text { value }\end{array}$ & 1 & 1 & 9 & 11 & 0 & 0 & 2 & 2 & 0 & 0 & 2 & 2 & 0 & 1 & 4 & 5 \\
\hline $\begin{array}{l}\text { Gun } \\
\text { availability }\end{array}$ & 0 & 6 & 15 & 21 & 0 & 1 & 2 & 3 & 0 & 2 & 1 & 3 & 0 & 2 & 9 & 11 \\
\hline Retaliation & 2 & 13 & 44 & 59 & 2 & 8 & 42 & 52 & 0 & 2 & 0 & 2 & 0 & 0 & 1 & 1 \\
\hline Other & 0 & 8 & 9 & 17 & 0 & 2 & 1 & 3 & 0 & 2 & 3 & 5 & 0 & 4 & 2 & 6 \\
\hline Total & 11 & 66 & 175 & 252 & 4 & 32 & 92 & 128 & 1 & 9 & 23 & 33 & 1 & 11 & 39 & 51 \\
\hline
\end{tabular}

${ }^{1}$ All fauna in general, including those (e.g. fish, reptiles and amphibians) that do not fall within the other three categories (carnivores, ungulates, birds)

${ }^{2}$ Includes snow leopard, wolf and other carnivores

${ }^{3}$ Includes odd-toed (horses, asses, tapirs) and even-toed ungulates (sheep, goats, gazelles)

${ }^{4}$ Includes upland game birds, waterfowl, predatory birds, and other birds 
talk about an activity and markets that are generally considered to be illegal, we identified informants through snowball sampling (Biernacki \& Waldorf, 1981). We implemented the survey in mid 2014, soliciting responses through the online survey software Qualtrics (Qualtrics, Provo, USA) from informants who had access to the internet (mostly employees of environmental NGOs; $n=9)$, and in person otherwise $(n=48)$. In-person interviews were conducted by Afghans, and all respondents were informed that the survey results would be used for the university thesis of an Afghan student.

Respondents As potential respondents we considered hunters, community representatives, vendors in wildlife markets, and experts with relevant scientific background or work experience with environmental organizations. Of 98 potential participants both outside and in Afghanistan, 57 people responded to the survey (Table 2). Participants from outside Afghanistan consisted of international staff members and Afghan scholars who had previously worked for Afghan conservation organizations (National Environmental Protection Agency, Ministry of Agriculture, Irrigation and Livestock, the United Nations Environment Programme, and Kabul University). Participants in Afghanistan were selected from three provinces: Kabul, Bamiyan and Badakhshan. Bamiyan and Badakhshan contain the country's two National Parks (Band-e-Amir and Wakhan) within their territories, heightening concern about human impacts on wildlife in these provinces. Kabul was selected because it contains the two most important wildlife markets in Afghanistan, Ka Farushi bird market and Koch-e Murgh Frushi (Chicken Street) market, where we interviewed vendors, hunters, and residents of communities known to have frequent negative interactions with wildlife. Thus, our survey respondents had experience and knowledge, and a wide range of perspectives on wildlife in Afghanistan.

Survey instrument To elicit information on the reasons for hunting we asked respondents to list species that are hunted, and the reasons they are hunted. Both were open-ended questions. The questionnaire also posed closed-ended questions about the overall importance of the factors identified in the initial review of the literature: subsistence consumption; medicine; retaliatory killing; fur and other by-products; pet and live trade; recreation; and high demand in international markets; as well as two other factors reported in the media: foreign trophy hunters, and demand from foreigners who live and work in Afghanistan. Respondents rated the importance of each factor on a scale, from $1=$ least important to $7=$ most important. In addition, respondents were asked to rate the status of wildlife, from $1=$ excellent to $7=$ highly threatened, and hunting intensity in Afghanistan, from $1=$ none to
$7=$ very heavy. The questions were posed about conditions in Afghanistan in general. All survey material, including the questionnaire, consent letter and ethics agreement form, were reviewed and approved by the North Carolina State University Institutional Review Board for the use of Human Subjects in Research (IRB \#4013). We presented each informant with a consent letter and research ethics agreement. Because of the sensitive nature of the subject, we asked respondents about motivations for hunting in general, not specifically whether they hunted and why. All survey materials were written in English and then translated to Dari (one of Afghanistan's two national languages). To test the accuracy of the translation we used the back-translation technique (Brislin, 1970). The Dari version was translated into English by an independent translator, and compared to the original English questionnaire. We found no discrepancies.

Data coding and analysis After recording lists of species hunted and reasons for hunting, we categorized them and counted the numbers of respondents who cited various factors for each category of species. To categorize species, we subdivided the species groups used to organize findings from the literature. Specifically, we disaggregated carnivores, placing the snow leopard and wolf Canis lupus in categories of their own because they were mentioned as species of concern by many respondents. We also disaggregated birds into four categories (upland game, waterfowl, predatory, and other). We added two more categories: other mammals, and fish. Respondents cited the four factors mentioned most frequently in the literature (subsistence consumption, fur and other by-products, pet and live trade, and retaliatory killing), as well as medicine and recreation. To explore patterns of beliefs about the status of wildlife, hunting intensity and motivations for hunting in general in Afghanistan, we calculated and compared mean responses across various types of respondents and various regions, and we estimated descriptive ordinary least square regression models using Statistix 10 (Analytical Software, Tallahassee, USA).

\section{Results}

The findings in the literature reflect the frequency with which researchers have studied particular species groups and factors associated with hunting in Afghanistan. We found most research addressed trade in fur and other byproducts ( 74 cases) and retaliation (59 cases), where a case is defined as one species considered by one study. Fur and other by-products, and retaliation, were found to be the most important factors in 62 and $74 \%$, respectively, of the 
TABLE 2 Demographic characteristics of 57 respondents to a survey about hunting in Afghanistan.

\begin{tabular}{ll}
\hline & No. of respondents (\%) \\
\hline Male respondents & $54(95)$ \\
Female respondents & $3(5)$ \\
Mean age \pm SD (years) & $39 \pm 13$ \\
Location & \\
Kabul (vendors in wildlife markets) & $9(16)$ \\
Kabul (wildlife experts from MAIL and & $24(42)$ \\
$\quad$ NEPA) & \\
Bamyan & $11(19)$ \\
Badakhshan & $9(16)$ \\
Outside Afghanistan & $4(7)$ \\
\hline
\end{tabular}

${ }^{*}$ MAIL, Ministry of Agriculture and Livestock; NEPA, National Environmental Protection Agency

cases in which they were studied. In contrast, subsistence consumption and live trade were studied less than half as often ( 25 cases each) but were found to be the most important factor in $80 \%$ of those cases. Research focus on the fur trade and retaliatory killing may be driven by scientists' interest in carnivores. In the literature on carnivores the trade in fur and other by-products, and retaliatory killing, were the most frequently studied factors and most often found to be important motivations for hunting. However, subsistence consumption was found to be important more often in the case of ungulates, whereas for birds the live and pet trade was the key factor.

Thus, according to a simple summary of the literature, Afghanistan's wildlife is most likely to be hunted for fur, followed by retaliatory killing (Table 1 ). Of a total of 252 findings reported in the literature, 24 identified trade in fur and other by-products as one of several factors associated with hunting, and an additional 46 characterized the fur trade as the most important factor (Table 1). The second most frequently reported motivation for hunting was retaliatory killing. There were 13 reports of retaliatory killing as a motivation for hunting, and 44 reports that it was the most important factor (Table 1). Table 1 also lists 10 other factors mentioned less frequently than fur and retaliation.

\section{Evidence from the interviews on motivations for hunting in general}

Based on the survey Likert scale (Likert, 1932), the most important motivations for hunting in Afghanistan in general were (1) subsistence consumption and (2) fur and other by-products, followed by (3) pet and live trade, (4) retaliatory killing, and (5) high international market demand (Fig. 2). Based on a $95 \%$ confidence interval $\left(2^{\star} \mathrm{SE}\right)$, these five motivations were significantly more important than the lowest rated motivations (medicine, recreational hunting, and trophy hunting). Ungulates were the group targeted by hunters most often $(n=45)$, followed by snow leopards $(n=39)$ and other predators, such as foxes Vulpes spp., cats Felis spp. and stone martens Martes foina $(\mathrm{n}=31)$ (Table 3).

\section{Hunting motivation by species group}

We considered the motivations for hunting various groups of species, drawing on the evidence from the published literature (Table 1) and the survey responses (Table 3). Both the literature and key informants identified the fur trade and retaliation as key motivations for hunting of carnivores. The vote count of the literature suggests Afghanistan's carnivores are threatened firstly because of the high value placed on their fur and secondly because of the damage they cause to livestock, which provokes retaliatory killing. In 20 cases, researchers concluded that trade in fur is a factor in hunting Afghanistan's carnivores, and in 37 cases they found that the fur trade was the most important factor (Table 1). Retaliatory killing was reported in the literature to be the most important motivation for hunting carnivores in 42 cases, and a motivation in eight other cases (Table 1). According to the survey, the most important reason for hunting snow leopards $(n=33)$ and other predators $(n=28)$ was fur and other by-products, whereas the most important motivation for hunting wolves was retaliatory killing $(\mathrm{n}=15)$. In the literature 11 studies found that subsistence consumption was the most important motivation for hunting of ungulates; however, one study concluded that subsistence consumption was not a factor in hunting of ungulates.

Our meta-analysis suggests the main factor in the hunting of birds in Afghanistan is the live trade, followed by gun availability. There were 13 statements claiming that live trade was an important motivation for hunting birds in Afghanistan, and two other statements reporting that live trade was a motivation. The literature also identified gun availability as a factor facilitating hunting: there were nine reports that gun availability was an important factor, although two studies claimed that it was not a factor (Table 1). Other factors cited in the literature include hunting for medicinal purposes and for international demand. Traditional medicinal uses reported in the literature include treating kidney disease by consuming the European roller Coracias garrulus (Moheb \& Mostafawi, 2012), and treating stomach and heart disease by consuming the dried gallbladder of the golden eagle Aquila chrysaetos (Ostrowski, 2006). Moreover, survey respondents stated that drinking the blood of a raven Corvus sp. and eating live fish were traditional remedies for asthma, and dried turtle meat was considered to be a remedy for haemorrhoids.

Survey respondents reported that the most threatened birds were predatory birds, such as falcons Falco spp. $(\mathrm{n}=27)$. Although officially it is not permitted, foreign hunters (e.g. from the Middle East and Pakistan) have been reported to hunt these species, which are also taken for pets and live 


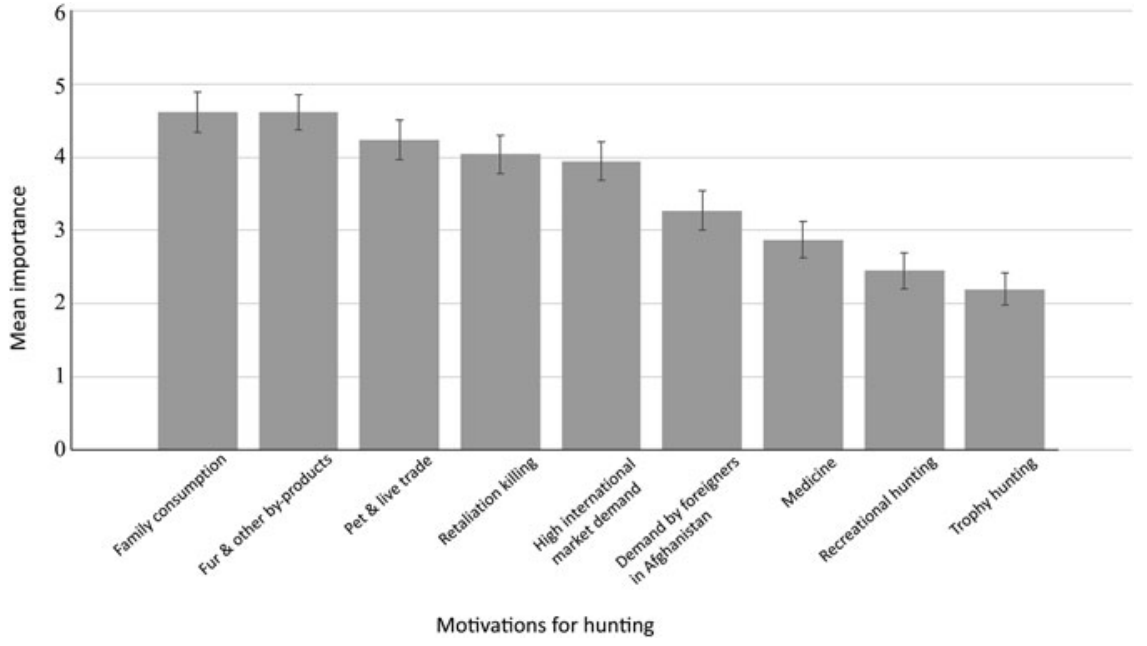

FIG. 2 Mean importance of each motivating factor $( \pm S E)$, on a scale of 1 (least important) to 7 (most important), based on interviews with 57 respondents. trade $(\mathrm{n}=23)$. Upland game birds, such as chukar partridge Alectoris chukar, quail Coturnix coturnix, pigeon Columba spp, and bustard Chlamydotis spp., are hunted for pets and live trade $(n=12)$ and for subsistence consumption $(n=12)$. Chukars are trapped and kept mainly for fighting purposes. Raptors are taken mostly for internal trade. Many small birds are kept as pets. Waterfowl, such as ducks, are hunted mainly for food $(n=17$; Table 3$)$.

\section{Beliefs about wildlife status and hunting intensity}

Although respondents recognized heterogeneity in hunting patterns and motivations across species groups, overall their mean rating of hunting intensity was 5.1 on a scale of $1-7$, which suggests they believed wildlife was hunted intensively in Afghanistan. Similarly, their mean rating of the status of wildlife in Afghanistan was 5.6 on a scale of 1-7, which suggests they believed Afghanistan's wildlife as a whole to be threatened. Hunting intensity was rated highest, and the status of wildlife was rated poorest by experts (i.e. professionals in government, civil society and universities) and by respondents in Kabul. In general, respondents who rated hunting intensity as higher or wildlife status as poorer also tended to rate all of the motivations and drivers as more important (i.e. give higher ratings to all factors in Fig. 2). However, the descriptive regressions reported in Tables 4 and 5 suggest respondents who believed the status of wildlife was worse or hunting was more intensive were more likely to identify particular motivations for hunting. Specifically, respondents who rated retaliatory killing $(\mathrm{P}=0.0048)$ and medicinal usage $(\mathrm{P}=0.0391)$ as more important tended to assess the overall status of wildlife as being worse, or more threatened (Table 4). Medicinal usage $(\mathrm{P}=0.0279)$ and recreational hunting $(\mathrm{P}=0.0477)$ have statistically significant relationships with the rating of hunting intensity (Table 5). There were also differences across types of respondents: experts were most likely to identify fur and other byproducts, and pet and live trade as the most important motivations, whereas merchants were more likely to identify medicine along with fur and other by-products, and people from communities near hunting areas were more likely to rate family consumption and retaliation as more important.

\section{Recommendations from key informants}

Most respondents (96\%) believed there were tools and policies that could help reduce hunting of wildlife in Afghanistan. Suggested deterrents were grouped into eight categories. The most common suggestion was to establish and enforce laws and regulations $(n=47 ; 38.5 \%)$. This is a critical challenge in Afghanistan and is related to the fourth most frequent recommendation: establishing security $(\mathrm{n}=11$; $9 \%)$. Circa $20 \%$ of respondents $(n=22(18 \%)$ and $n=21$ (17\%), respectively) suggested awareness, education and capacity building, and providing livelihood alternatives (Table 6).

Patterns of responses to the survey were consistent with the suggestion that education could help reduce hunting. A $\chi^{2}$ test indicated an association between education levels and the perceived status of wildlife $\left(\chi^{2}=9.485, \mathrm{P}=0.009\right)$. As our dataset does not meet the assumptions of the $\chi^{2}$ test, we confirmed this result with Fisher's exact test $(\mathrm{P}=0.0099)$. Specifically, respondents with higher education levels were more likely to report that Afghanistan's wildlife was threatened. We confirmed this by condensing the Likert scale responses into two categories, threatened $(\mathrm{n}=38)$ and not threatened $(n=19)$, and estimating a logistic model of the probability of reporting wildlife as threatened as a function of education level (where $1=$ uneducated/primary school, $2=$ high school/associate degree, and $3=$ university degree). The estimated regression coefficient on education level was positive (0.87386) and significant $(\mathrm{P}=0.01)$. Thus, respondents with more education were more aware and concerned about the threats to Afghanistan's wildlife, lending support to the idea that education could help to reduce hunting.

Education may be the underlying factor explaining why both professionals and respondents in Kabul rated the status 


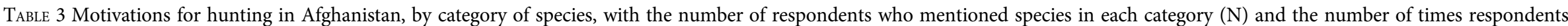

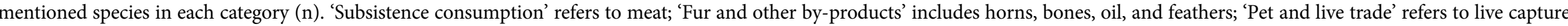

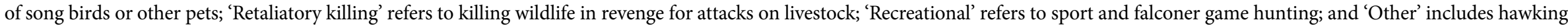
and hunting for amulets.

\begin{tabular}{|c|c|c|c|c|c|c|c|c|c|c|c|c|c|c|c|c|c|c|c|c|}
\hline \multirow[b]{2}{*}{ Motivations } & \multicolumn{2}{|c|}{$\begin{array}{l}\text { Snow leopard } \\
\text { Uncia uncia }\end{array}$} & \multicolumn{2}{|c|}{$\begin{array}{l}\text { Wolf Canis } \\
\text { lupus }\end{array}$} & \multicolumn{2}{|c|}{$\begin{array}{l}\text { Other } \\
\text { predators }{ }^{1}\end{array}$} & \multicolumn{2}{|c|}{ Ungulates $^{2}$} & \multicolumn{2}{|c|}{$\begin{array}{l}\text { Other } \\
\text { mammals }\end{array}$} & \multicolumn{2}{|c|}{$\begin{array}{l}\text { Upland game } \\
\text { birds }^{4}\end{array}$} & \multicolumn{2}{|c|}{ Waterfowl $^{5}$} & \multicolumn{2}{|c|}{$\begin{array}{l}\text { Predatory } \\
\text { birds }^{6}\end{array}$} & \multicolumn{2}{|c|}{ Other birds ${ }^{7}$} & \multicolumn{2}{|l|}{ Fish } \\
\hline & $\mathrm{N}=39$ & $\mathrm{n}=51$ & $\mathrm{~N}=25$ & $\mathrm{n}=31$ & $\mathrm{~N}=31$ & $\mathrm{n}=61$ & $\mathrm{~N}=45$ & $\mathrm{n}=109$ & $\mathrm{~N}=4$ & $\mathrm{n}=4$ & $\mathrm{~N}=20$ & $\mathrm{n}=37$ & $\mathrm{~N}=19$ & $\mathrm{n}=27$ & $\mathrm{~N}=27$ & $\mathrm{n}=32$ & $\mathrm{~N}=1$ & $\mathrm{n}=14$ & $\mathrm{~N}=9$ & $\mathrm{n}=11$ \\
\hline $\begin{array}{l}\text { Subsistence } \\
\text { consumption }\end{array}$ & & & & & 1 & 1 & 43 & 64 & & & 12 & 16 & 17 & 21 & & & 8 & 8 & 8 & 8 \\
\hline $\begin{array}{l}\text { Fur, horns \& } \\
\text { other } \\
\text { by-products }\end{array}$ & 33 & 33 & 15 & 13 & 28 & 45 & 20 & 33 & 1 & 1 & & & 5 & 6 & & & & & 1 & 1 \\
\hline $\begin{array}{l}\text { Pet \& live } \\
\text { trade }\end{array}$ & 7 & 9 & & & 6 & 7 & 3 & 3 & 1 & 1 & 12 & 18 & 1 & 1 & 23 & 27 & 2 & 3 & 1 & 1 \\
\hline $\begin{array}{l}\text { Retaliatory } \\
\text { killing }\end{array}$ & 8 & 8 & 15 & 15 & 5 & 7 & & & 1 & 1 & & & & & & & 3 & 3 & & \\
\hline Medicine & & & & & & & & & 2 & 1 & 2 & 3 & & & & & & & 1 & 1 \\
\hline Recreational & & & 1 & 1 & 1 & 1 & 4 & 9 & & & & & 1 & 1 & & & 3 & 3 & & \\
\hline Other & 1 & 1 & & & & & & & & & 1 & 1 & & & 5 & 5 & 1 & 1 & & \\
\hline
\end{tabular}

${ }^{1}$ Includes foxes, dogs, cats, stone martens, lynxes and jackals

${ }^{2}$ Includes odd-toed (horses, asses, tapirs) and even-toed ungulates (sheep, goats, gazelles)

${ }^{3}$ Cape hares Lepus capensis

${ }^{4}$ Includes common quails, partridges, pigeons and bustards

${ }^{5}$ Includes ducks

${ }^{6}$ Includes falcons and eagles

Includes finches and fire-fronted serins Serinus pusillus 
TABLE 4 Model of perceived wildlife status as a function of the perceived importance of various motivations for hunting (ordinary least square, $\mathrm{N}=57$ ). Wildlife status was rated from excellent (1) to highly threatened (7), and each motivating factor from least important (1) to most important (7). Model statistics: $\mathrm{R}^{2}=0.4724$, $\mathrm{F}=3.48, \mathrm{P}=0.0037$.

\begin{tabular}{lrlrl}
\hline Motivations for hunting & \multicolumn{1}{l}{ Coeff } & SE & \multicolumn{1}{l}{ T } & \multicolumn{1}{l}{$\mathrm{P}$} \\
\hline Subsistence consumption & -0.121 & 0.100 & -1.21 & 0.233 \\
Medicine & 0.249 & 0.116 & 2.14 & 0.039 \\
Fur \& other by-products & 0.100 & 0.142 & 0.70 & 0.487 \\
Retaliatory killing & 0.335 & 0.111 & 3.02 & 0.005 \\
Pet \& live trade & -0.080 & 0.125 & -0.64 & 0.526 \\
$\quad$ Demand in international & 0.219 & 0.160 & 1.36 & 0.181 \\
$\quad$ markets & & & & \\
$\quad$ Demand from foreigners living & -0.066 & 0.115 & -0.58 & 0.568 \\
$\quad$ \& working in Afghanistan & & & & \\
Foreign trophy hunting & -0.041 & 0.187 & -0.22 & 0.826 \\
$\quad$ Recreation & 0.170 & 0.127 & 1.34 & 0.189 \\
\hline
\end{tabular}

of wildlife as worse, on average, compared to other types of respondents in other regions of the country. Alternatively, the correlation between education and perception of wildlife status may reflect the fact that more educated respondents live in urban settings where damage to wildlife is less problematic and there are more livelihood options. Although this correlation does not demonstrate causality, it is consistent with the idea that better education and livelihood options could help reduce hunting pressure.

The most commonly cited motivations for hunting most categories of species were related to livelihoods; for example, most respondents suggested that ungulates and waterfowl were hunted for food, whereas snow leopards and other predators were hunted for fur and other products that could be sold. Retaliatory killing of wolves could be considered to be a form of livelihood protection. Providing livelihood alternatives could therefore help to address one of the key underlying motivations for hunting.

\section{Discussion}

Our findings suggest that researchers' focus on carnivores may have obscured the importance of consumption as a motivation for hunting in Afghanistan. Our meta-analysis showed that the fur trade and retaliation were important motivations for hunting but that retaliatory killing was specific to carnivores. Our survey identified the same factors but suggested that meeting family consumption needs was also critical. Ungulates in particular were hunted mainly for consumption. This supports previous research on ungulates and subsistence demand for meat; for example, in Badakhshan ibex Capra sibirica are commonly hunted for consumption (Ostrowski et al., 2008), and musk deer Moschus cupreus are hunted not only for the commercial value of their musk pods and skins but also for their meat
TABLE 5 Model of perceived hunting intensity as a function of perceived importance of motivations for hunting (ordinary least square, $\mathrm{N}=57$ ). Hunting intensity was rated on a scale from no hunting (1) to very heavy hunting (7), and each motivating factor was rated on a scale from least important (1) to most important (7). Model statistics: $\mathrm{R}^{2}=0.5112, \mathrm{~F}=4.07, \mathrm{P}=0.0012$

\begin{tabular}{lrlrl}
\hline Motivations for hunting & Coeff & SE & T & P \\
\hline Subsistence consumption & 0.044 & 0.096 & 0.46 & 0.646 \\
Medicine & 0.255 & 0.111 & 2.29 & 0.028 \\
Fur \& other by-products & 0.196 & 0.136 & 1.44 & 0.160 \\
Retaliatory killing & 0.029 & 0.106 & 0.27 & 0.787 \\
$\quad$ Pet \& live trade & 0.004 & 0.120 & 0.03 & 0.975 \\
$\quad$ Demand in international & 0.166 & 0.153 & 1.08 & 0.287 \\
$\quad$ markets & & & & \\
$\quad$ Demand from foreigners living & 0.101 & 0.110 & 0.91 & 0.369 \\
$\quad$ \& working in Afghanistan & & & & \\
$\quad$ Trophy hunting by foreigners & -0.138 & 0.179 & -0.77 & 0.445 \\
$\quad$ Recreation & 0.250 & 0.122 & 2.05 & 0.048 \\
\hline
\end{tabular}

(Sayer \& Van der Zon, 1981; Habibi, 2003; Karlstetter, 2008). One important underlying factor was the high rate of rural poverty, which meant that people could not afford to buy meat in the market (UNDP, 2006).

Other motivations for hunting varied with species type, species availability in a given area, and market demands; for example, our survey results suggest that snow leopards are hunted mainly for fur and other by-products but wolves are hunted mainly in retaliation. As wolves are found at lower altitudes and live closer to livestock, they are more likely to attack sheep and goats, and to be shot by community members. In contrast, snow leopards are found at higher altitudes and far from human settlements, and therefore they are more likely to kill their natural prey, and on rare occasions yaks Bos grunniens (Habib, 2008). Market prices also influence motivations for hunting various species; for example, unlike wolves, snow leopards are commonly hunted for their fur because snow leopard skins command a significantly higher price. In 2004 a single snow leopard skin could be sold for USD 300 (Mishra \& Fitzherbert, 2004), whereas a wolf skin commanded no more than USD 50 in 2013 (Moheb \& Mostafawi, 2013).

Our survey of key informants had some limitations. Firstly, we conducted interviews in only three geographical areas (Kabul, Bamyan and Badakhshan), with a small and non-random sample. Secondly, because the context of this study was somewhat sensitive (illicit hunting and markets), the respondents may have been reluctant to provide full information. Future research could consider adopting survey methods for sensitive topics (cf. Couper et al., 2003; Joinson et al., 2007; Tourangeau \& Yan, 2007; Yu et al., 2008). Our study was also limited by its focus on hunting, without considering habitat degradation. Another limitation of our survey, and much of the literature, is that research has been based largely on information obtained 
TABLE 6 Number of respondents who mentioned specific tools and policies for deterring illegal hunting, and percentage of all mentions of deterrents $(n=122)$, based on interviews of 57 people.

\begin{tabular}{lll}
\hline Deterrents of illegal hunting & $\begin{array}{l}\text { No. of } \\
\text { respondents }\end{array}$ & $\begin{array}{l}\text { \% of all mentions } \\
\text { of deterrents }\end{array}$ \\
\hline $\begin{array}{l}\text { Establishing \& enforcing } \\
\text { laws \& regulations }\end{array}$ & 47 & 38.5 \\
$\begin{array}{l}\text { Awareness, education \& } \\
\quad \text { capacity building }\end{array}$ & 22 & 18.0 \\
$\begin{array}{l}\text { Providing livelihood } \\
\text { alternatives }\end{array}$ & 21 & 17.2 \\
$\begin{array}{l}\text { Establishing security } \\
\begin{array}{l}\text { Funding sustainable wildlife } \\
\text { management programmes }\end{array}\end{array}$ & 11 & 9.0 \\
$\begin{array}{l}\text { Cooperation } \\
\text { Monitoring \& evaluation of } \\
\text { markets }\end{array}$ & 3 & 6.6 \\
\begin{tabular}{l} 
Other deterrents \\
\hline
\end{tabular} & 5 & 4.1 \\
\hline
\end{tabular}

from respondents who are active in wildlife markets and are therefore more likely to be familiar with commercial motivations for hunting than with hunting for subsistence consumption.

Nevertheless, our findings show that different policy tools are required to address hunting for different species groups in Afghanistan. Although hunting has been banned, the country lacks the necessary funds, resources and personnel to prevent it. Killing wildlife for consumption is hard to deter for philosophical and practical reasons: hungry people are a social problem and evoke sympathy, and consequently regulations are not enforced. Social policies supporting food production and distribution systems, and preventing theft of livestock would probably help but are not easy to implement (Tariq et al., 2012). The live bird trade might be combatted most effectively by reducing demand, identifying and sanctioning those engaged in the illegal purchase of birds in consumer markets; however, this would require considerable political will and could instigate resistance and radicalization because of the central cultural role of wildlife markets (the bird market has long been the main market in Kabul; Rodenburg, 1977; von Essen et al., 2015). Perhaps preventing hunting for illegal export and sale to foreigners would have the most political appeal, if adequate enforcement could be mustered.

Incentives could be used to help address retaliatory killing, such as offering livestock owners compensation for livestock lost to predators, and/or permits to kill identified problem individuals. However, rural residents often make apparently excessive claims about wild predators killing livestock (Moheb \& Mostafawi, 2013). Installing predatorresistant corrals in predation hotspots identified by community members is another potential tool for addressing this problem (Simms et al., 2011). Key informants suggested that one of the most effective deterrents of hunting in general would be education and awareness programmes to change people's attitudes towards trophies and live birds, and the killing of wildlife to supply the international market.

Greater stability and peace in Afghanistan is the fundamental change most likely to benefit the country's wildlife and rural residents. Other policy recommendations hinge on such stability. For example, formally adopting and developing specific regulations to implement wildlife management laws are unlikely to become priorities while the country faces significant threats to public security and the rule of law. Furthermore, enforcing such laws is likely to take precedence only once people are protected from constant threats to their personal safety and survival (Gaston $\&$ Wright, 2009; Tariq et al., 2012). All of the policy options suggested by our survey respondents will become more viable as Afghanistan regains political and economic stability.

\section{Acknowledgements}

We are grateful to the United States Agency for International Development for funding. We thank Ted Shear and Celia Eicheldinger for their advice on the statistical analysis. For their assistance with data collection we thank Fahim Nabi and Sayed Hamayoon Jalal, and the staff of the Wildlife Conservation Society Afghanistan programme, including Richard Paley, Qais Sahar, Arif Rahimi, Hafiz Rahmani, Shogofa Popal, Mohammad Ibrahim Abrar, Anthony Simms and Naqib Mostafawi.

\section{Author contributions}

MB reviewed the literature and implemented the survey of key informants. All authors contributed to study design, questionnaire development, data analysis and writing the article.

\section{References}

A tmadja, S. \& Sills, E. (2015) Identifying the Cause of Tropical Deforestation: Meta-analysis to Test and Develop Economic Theory. Springer-Verlag, Berlin, Germany.

Ayling, J. (2013) What sustains wildlife crime? Rhino horn trading and the resilience of criminal networks. Journal of International Wildlife Law \& Policy, 16, 57-80.

Benitez-López, A., Alkemade, R. \& Verweij, P.A. (2010) The impacts of roads and other infrastructure on mammal and bird populations: a meta-analysis. Biological Conservation, 143, 13071316.

Biernacki, P. \& Waldorf, D. (1981) Snowball sampling: problems and techniques of chain referral sampling. Sociological Methods \& Research, 10, 141-163.

Boglioli, M. (2009) A Matter of Life and Death: Hunting in Contemporary Vermont. University of Massachusetts Press, Amherst, USA.

BRISLIN, R.W. (1970) Back-translation for cross-cultural research. Journal of Cross-Cultural Psychology, 1, 185-216. 
CEBC (Centre for Evidence-Based Conservation) (2009) Guidelines for Systematic Review in Conservation and Environmental Management. CEBC, Bangor University, Bangor, UK.

Couper, M.P., Singer, E. \& Tourangeau, R. (2003) Understanding the effects of audio-CASI on self-reports of sensitive behavior. Public Opinion Quarterly, 67, 385-395.

Eliason, S.L. (2004) Accounts of wildlife law violators: motivations and rationalizations. Human Dimensions of Wildlife, 9, 119-131.

Formoli, T.A. (1995) Impact of the Afghan-Soviet war on Afghanistan's environment. Environmental Conservation, 22, 66-69.

Gaston, E.L. \& Wright, R. (2009) Losing the People: The Costs and Consequences of Civilian Suffering in Afghanistan. Http:// civiliansinconflict.org/uploads/files/publications/losing-thepeople_2009.pdf [accessed 5 December 2016].

НАвів, B. (2008) Status of Mammals in Wakhan Afghanistan. Unpublished report. Wildlife Conservation Society, New York, USA.

Hавіві, K. (2003) Mammals of Afghanistan. Zoo Outreach Organization, Coimbatore, India.

Joinson, A.N., Woodley, A. \& Reips, U.D. (2007) Personalization, authentication and self-disclosure in self-administered Internet surveys. Computers in Human Behavior, 23, 275-285.

Kahler, J.S. \& Gore, M.L. (2012) Beyond the cooking pot and pocket book: factors influencing noncompliance with wildlife poaching rules. International Journal of Comparative and Applied Criminal Justice, 36, 103-120.

Karlstetter, M. (2008) Wildlife Surveys and Wildlife Conservation in Nuristan, Afghanistan. Wildlife Conservation Society, New York, USA, and United States Agency for International Development, Washington, D.C., USA.

Likert, R. (1932) A technique for the measurement of attitudes. Archives of Psychology, 22, 55.

Mancini, A., Senko, J., Borquez-Reyes, R., Póo, J.G., Seminoff, J. A. \& KocH, V. (2011) To poach or not to poach an endangered species: elucidating the economic and social drivers behind illegal sea turtle hunting in Baja California Sur, Mexico. Human Ecology, 39, 743-756.

Manning, R.B. (1993) Hunters and Poachers: A Social and Cultural History of Unlawful Hunting in England, 1485-1640. Clarendon Press, Oxford, UK.

Mishra, C. \& Fitzherbert, A. (2004) War and wildlife: a post-conflict assessment of Afghanistan's Wakhan Corridor. Oryx, 38, 102-105.

Mонев, Z. \& Mostafawi, N. (2012) Biodiversity Reconnaissance Survey in Darwaz Region, Badakhshan Province, Afghanistan. Unpublished report. Wildlife Conservation Society, New York, USA, and United States Agency for International Development, Washington, D.C., USA.

Moneb, Z. \& Mostafawi, N. (2013) Biodiversity Reconnaissance Survey, Mayamai District, Darwaz Region, Badakhshan Province, Afghanistan. Unpublished report. Wildlife Conservation Society, New York, USA, and United States Agency for International Development, Washington, D.C., USA.

Moher, D., Liberati, A., Tetzlaff, J., Altman, D.G. \& The PRISMA Group (2009) Preferred reporting items for systematic reviews and meta-analyses: the PRISMA statement. PLoS Medicine, 6(7), e1000097.

Osborne, H. \& Winstanley, M. (2006) Rural and urban poaching in Victorian England. Rural History, 17, 187-212.

Ostrowski, S. (2006) A Rare Case of Golden Eagle (Aquila chrysaetos) Destruction for Use in Traditional Medicine, Wakhan, Afghanistan.
Unpublished report. Wildlife Conservation Society, New York, USA.

Ostrowski, S., Rajabi, A.M. \& Noori, H. (2008) Birds and Mammals in Dasht-e Nawar, Afghanistan: Occurrence and Hunting Pressure, 2007 Surveys. Unpublished report. Wildlife Conservation Society, New York, USA.

Pattanayak, S.K., Mercer, D.E., Sills, E. \& YAng, J.-C. (2003) Taking stock of agroforestry adoption studies. Agroforestry Systems, $57,173-186$.

Peterson, M.N., von Essen, E., Hansen, H.P. \& Peterson, T.R. (2016) Illegal fishing and hunting as resistance to neoliberal colonialism. Crime, Law and Social Change, http://dx.doi.org/1o. 1007/s10611-016-9664-0.

Raichev, E. \& Georgiev, D. (2012) Hunters' attitude to some protected mammals and birds in Bulgaria. Trakia Journal of Sciences, 10, 48-51.

Rodenburg, W.F. (1977) The Trade in Wild Animal Furs in Afghanistan. UNDP, FAO \& Ministry of Agriculture, Irrigation and Livestock, Kabul, Afghanistan.

SAYer, J.A. \& VAn Der Zon, A.P.M. (1981) National Parks and Wildlife Management, Afghanistan: A Contribution to a Conservation Strategy. Volume 1. UNDP \& FAO, Kabul, Afghanistan.

Simms, A., Moheb, Z., Salahuding, Ali, H., Ali, I. \& Wood, T. (2011) Saving threatened species in Afghanistan: snow leopards in the Wakhan Corridor. International Journal of Environmental Studies, 68, 299-312.

Tariq, M.O., Haqbeen, F.R. \& Kakar, P.L. (2012) Afghanistan in 2012: A Survey of the Afghan People. The Asia Foundation, San Francisco, USA.

Tourangeau, R. \& Yan, T. (2007) Sensitive questions in surveys. Psychological Bulletin, 133, 859-883.

UNDP (United Nations Development Programme) (2006) UNDP Afghanistan Annual Report. UNDP, Kabul, Afghanistan.

UNEP (United Nations Environment Programme) (2003) Afghanistan Wakhan Mission Technical Report. UNEP, Geneva, Switzerland.

UNEP (United Nations Environment Programme) (2013) Natural Resource Management and Peacebuilding in Afghanistan. UNEP, Kabul, Afghanistan.

von Essen, E., Hansen, H.P., Källström, H.N., Peterson, M.N. \& Peterson, T.R. (2014) Deconstructing the poaching phenomenon a review of typologies for understanding illegal hunting. British Journal of Criminology, 54, 632-651.

von Essen, E., Hansen, H.P., Källström, H.N., Peterson, M.N. \& Peterson, T.R. (2015) The radicalisation of rural resistance: how hunting counterpublics in the Nordic countries contribute to illegal hunting. Journal of Rural Studies, 39, 199-209.

Yu, J.-W., Tian, G.-L. \& TAnG, L. (2008) Two new models for survey sampling with sensitive characteristic: design and analysis. Metrika, $67,251-263$.

\section{Biographical sketches}

MujTABA BASHARI's research focuses on biodiversity conservation and management in Afghanistan. ERIN SILLS' research focuses on impact evaluation of forest conservation policies in the tropics. NiLs PETERSON's research focuses on the drivers of environmental behaviour, particularly in the contexts of environmental education, conservation development, and biodiversity conservation conflict. Frederick Cubbage teaches and conducts research on natural resource policy and forest economics. 